\title{
DIVERSE APPROACHES TO QUESTIONS OF BIODIVERSITY: GERMAN CONTRIBUTIONS TO STUDIES OF MARINE BENTHOS AROUND SOUTH AMERICA AND ANTARCTICA
}

\section{DISTINTOS ENFOQUES SOBRE PREGUNTAS ACERCA DE LA BIODIVERSIDAD: CONTRIBUCIONES ALEMANAS A LOS ESTUDIOS BENTONICOS EN AMERICA DEL SUR Y LA ANTARTIDA}

\author{
Julian Gutt ${ }^{1}$, Wolf E. Arntz ${ }^{1}$ Eduardo Balguerias ${ }^{2}$, Angelika Brandt ${ }^{3}$, Dieter Gerdes ${ }^{1}$, \\ Matthias Gorny ${ }^{4} \&$ Boris Sirenko \\ ${ }^{1}$ Alfred Wegener Institute for Polar and Marine Research. Columbusstr, D - 27568 Bremerhaven, Germany \\ +corresponding author: jgutt@awi-bremerhaven.de \\ ${ }^{2}$ Centro Oceanográfico de Canarias, Instituto Español de Oceanografía, Carretera San Andrés s/n 38120, Santa Cruz \\ de Tenerife, España \\ ${ }^{3}$ Zoological Institute and Zoological Museum, Martin-Luther-King-Platz 3, 20146 Hamburg, Germany \\ ${ }^{4}$ Instituto de la Patagonia, Universidad de Magallanes, Punta Arenas, Chile \\ ${ }^{5}$ Zoological Institute, Russian Academy of Science, Universitetskaya EMB 1, St. Petersburg 199034, Russia
}

\begin{abstract}
A look at the latitudinal gradient from North America via South America to Antarctica supports the impression that the ecosystems of this part of the world provide perfect conditions for marine biodiversity studies. Several bilateral or international initiatives with major German contributions have focused on biodiversity questions, especially in South America and Antarctica. At depths $>50 \mathrm{~m}$ accessible to shipboard sampling, an oxygen minimum zone (OMZ) prevails off Peru and Chile (except in the extreme south). The macrobenthic biota associated with the OMZ are extremely poor but show a gradient of increasing diversity at great depths and towards the south. In the southern Chilean fjords and channels, habitat heterogeneity is high and differences in the fauna can be observed over even small distances, especially in the Magellan area. A high intra-habitat biodiversity can, thus, be expected. On the exposed deep shelf around Antarctica, a large-scale gradient between a community dominated by a very high biomass and abundance of sessile suspension feeders can be distinguished from a community with significantly fewer epifauna. However, their relationships to the environmental conditions are still poorly understood. For the future, two approaches are recommended, the study of zoogeographical questions in the light of evolution and the identification of the key processes, including environmental changes, that engender biodiversity patterns.
\end{abstract}

KeYwords: Marine biodiversity, South America, Antarctica.

\section{RESUMEN}

Una mirada al gradiente latitudinal desde América del Norte vía Sur América hasta la Antártica sustenta la impresión que los ecosistemas de esta parte del mundo proveen condiciones perfectas para estudios de biodiversidad marina. Diversas iniciativas bilaterales e internacionales con mayores aportes alemanes se han concentrado en preguntas de biodiversidad especialmente en América del Sur y la Antártica. A profundidades $>50 \mathrm{~m}$ accesibles a muestreos desde embarcaciones, una zona de mínimo oxígeno (OMZ) predomina en Perú y Chile (excepto en el extremo sur) con una vida macrobentónica extremadamente pobre, mostrando un gradiente de incremento de diversidad a profundidades mayores y en sentido sur. En los fiordos y canales al sur de Chile la heterogeneidad del hábitat parece ser muy alta y claras diferencias faunísticas pueden ser observadas a cortas distancias, especialmente en la región de Magallanes. Como consecuencia se puede esperar una alta biodiversidad entre-hábitats ("between-habitat"). En la plataforma expuesta profunda alrededor de la Antártica un gradiente a gran escala entre una comunidad dominada por suspensívoros sésiles revelando biomasa y abundancia altas, puede ser distinguida de una comunidad con muy poca epifauna. Sin 
embargo, las relaciones con parámetros ambientales son todavía vagamente entendidas. Para el futuro se recomiendan dos enfoques, estudiar preguntas zoogeográficas a la luz de la evolución e identificar procesos clave que desplieguen patrones de biodiversidad incluyendo cambios ambientales.

Palabras claves: Biodiversidad marina, América del Sur, Antártica.

\section{INTRODUCTION}

Are South American waters suitable for BIODIVERSITY STUDIES OF GENERAL RELEVANCE?

An improvement in our knowledge of the world's faunal inventory and the processes leading to biodiversity is of fundamental relevance, as has been recognized during the past decade, and has recently again been emphasized in the World Summit on Sustainable Global Development held in Johannesburg and by the international scientific initiative, "Census of Marine Life". However, much effort is still necessary to increase our present level of information significantly. One way to proceed may be (1) to investigate if biodiversity patterns and their specific dynamics can be explained in terms of regional environmental conditions and biological demands; and (2) to combine aspects of recent large-scale zoogeographical patterns with conclusions about their long-term development and the evolution of the species present.

South America provides perfect conditions to study both small and large scale marine biodiversity. If the adjacent continents to the north and south are included, latitudinal gradients can uniquely be investigated almost from pole to pole. For the longterm perspective, the littoral of South America is of particular interest to zoogeographers because it provides two predominantly latitudinal coastlines which, in areas with similar environmental conditions, can be used for comparative purposes. In addition, similar data from North America would show whether patterns observed in the southern hemisphere are reflected mirror-like in the north. This provides a basis for assessing whether general phenomena exist or whether more efficient regional phenomena are superimposed on latitudinal gradients. In this context, the long isolation of Antarctica (for about $20 \mathrm{Ma}$ ) may have led to specific developments so that the coastal waters of that continent could be regarded as an evolutionary incubator (Watling \& Thurston 1989). Comparative stud- ies on the continental shelves, in the deep sea between the two continents, and around islands which serve as stepping-stones for shallow fauna should elucidate the potential of dispersion and the effect of isolation of populations on their evolution. An example of such a study which provided comprehensive results on amphipods and isopods in this context is that of Wägele $(1992,1994)$.

South American waters provide a large variety of different benthic systems and subsystems: coral reefs and mangroves in the north; upwelling systems with extended oxygen minimum zones (OMZ) at medium depths and narrow shelves exposed to the open ocean at intermediate latitudes; fjords, bays, and straits in the south (see e.g. Brattström \& Johanssen 1983, Lancellotti \& Vásquez 1999). This variety is a good prerequisite for studying predominantly ecologically driven biodiversity patterns, and an advantageous basis for truly comparative studies for (1) assessing the role of diversity in ecosystem functioning and (2) identifying the factors that determine the complexity of biodiversity. Detailed knowledge of biological structures and processes is also urgently required to support authorities selecting conservation areas because human impacts on coastal marine ecosystems - by fisheries, aquaculture, tourism, and constructions - are dramatically increasing as is now occurring, for instance, in southern Chile. As part of such an applied approach, the development and structures of biodiversity patterns can also be modeled for, as yet, non-existing scenarios as in the case of large scale, presumably anthropogenic, changes such as global warming.

INITIATIVES: RESEARCH ON MARINE BIODIVERSITY IN South AmErica AND ANTARCTICA - THE CONTRIBUtions By GERMAN SCIENTISTS

Fig. 1 provides a summary of the research programs on marine biodiversity in South America and Antarctica which have included German contributions. During the EPOS initiative (European "Polarstern" Study; Arntz et al. 1990) supported by the Euro- 


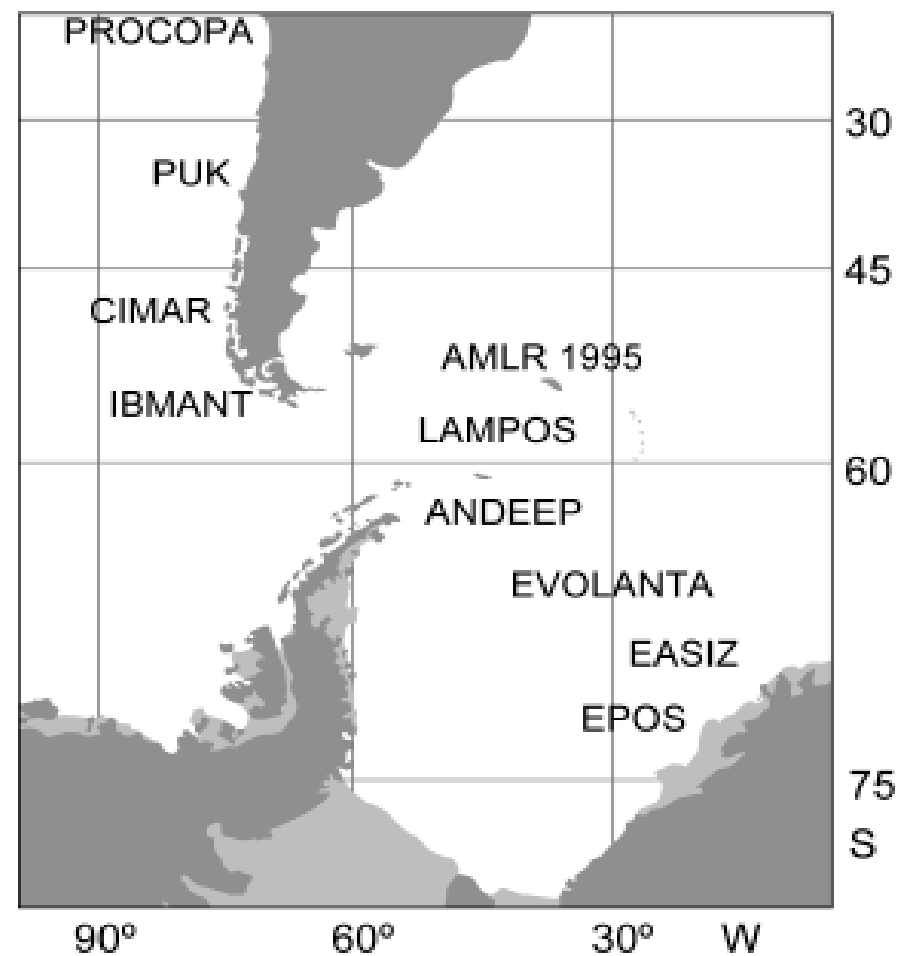

FIGURE 1: Research initiatives on benthic biodiversity in South America and Antarctica with German contributions (EPOS: European "Polarstern" Study, EASIZ: Ecology of the Antarctic Sea Ice Zone, EVOLANTA: Evolution in the Antarctic, ANDEEP: Antarctic Benthic Deep-sea Biodiversity, LAMPOS: Latin American "Polarstern" Study, AMLR: Antarctic Marine Living Resources, IBMANT: Interactions between the Magellan Region and the Antarctic, CIMAR: Marine science research cruise to the fjords and channels adjacent to the Southern Ice Fields, PUK: Interrelations between productivity and environmental conditions on the Chilean continental slope, PROCOPA: Join Peruvian-German fishing research Program, JOPS: Joint Oceanographic Projects, MADAM: Mangrove Dynamics and Management. Projects with acronyms in parentheses are not discussed in detail in this review.

FIgURA 1. Iniciativas de investigaciones en la biodiversidad béntica en América del Sur y la Antártica con contribuciones alemanas (EPOS: Estudio “Polastern” Europa, EASIZ: la Ecología de la Zona de Hielo Marino de la Antártica, LAMPOS: Estudio "Polastern" de América Latina, AMLR: Recursos Marinos vivos de la Antártica, IBMANT: las interacciones entre la región de Magallanes y la Antártica, CIMAR: Crucero de Investigación Científica Marina a los fiordos y canales adyacentes a Campos de Hielo Sur, PUK: las interrelaciones entre la productividad y las condiciones ambientales en la pendiente continental chilena, PROCOPA: Programa Cooperativa Peruano-Alemán de Investigación Pesquera, JOPS: Proyectos Conjuntos Oceanográficos, MADAM: Dinámica y Manejo de los Mangles. Los proyectos con acrónimos en paréntesis no son discutidos de forma detallada en este resumen.

pean Science Foundation in 1989, the macrobenthos and demersal fish fauna of the southeastern Weddell Sea, Antarctica, were intensively surveyed. Based on earlier experience (see e.g. Voss 1988, Piepenburg et al. 1997), 3 large sectors off Kapp Norvegia, Vestkapp, and Halley Bay, from the shelf ice edge to the deep sea, were investigated using a variety of sampling gear. The results provided an overall picture of biodiversity, biogeography, and zonation on the high Antarctic shelf and slope of the Atlantic sector and allowed the first comparisons with other large Antarctic areas, e.g. the Ross Sea and around the Antarctic Peninsula (Hempel 1993). They also stimulated further national and international programs. Due to their potential for providing a fast scientific overview of macroepibenthic systems, the documentation of the benthos by visual methods has been used since then and in most of the projects described below (Gutt 2001). 
A complementary program carried out to the north of the Drake Passage was IBMANT (Interactions between the Magellan Region and the Antarctic) with the 'Joint Magellan 'Victor Hensen' Campaign" in 1994 as the main activity (Arntz \& Gorny 1996; Arntz \& Ríos 1999). This joint Chilean-German-Italian expedition, which included participants from other countries, covered the Magellan channel system between Paso Ancho in the Straits of Magellan and the area south of the eastern mouth of the Beagle channel down to Cape Horn, working from shallow water out to $653 \mathrm{~m}$ depth. This cruise greatly increased the previously scant data available on benthic distribution, zonation, and biodiversity in the Magellan region. Later, this work was complemented by other expeditions, e.g. the "Polarstern" cruise ANT XIII/4 working on the continental slope east of Cape Horn from 99 to 2505 $m$ depth (Fahrbach \& Gerdes 1997) and various "Vidal Gormaz" cruises (see below) in the Magellan region, in close cooperation with the Magellan University in Punta Arenas. Much of this material has been analyzed and identified taxonomically, mostly with emphasis on certain taxa, and further work is underway to fill the gaps in the data. The results now available from both continents already provide a much improved base for the comparison of Antarctic and South American fauna. One of the major outcomes is that the "bell-shaped distribution" of species richness from the equator to the poles does not appear to hold for the southern hemisphere (Gallardo 1987), though some taxa such as the decapod crustaceans may reveal such a distribution (Boschi 2000). The more general picture of the Magellan-Antarctic gradient is illustrated by the peracarid crustaceans, which increase in species richness towards the south. Crame (1999) has provided more general concepts on latitudinal gradients.

The CIMAR FIORDO cruises (Cruceros de Investigacion Científica Marina a los Fiordos y Canales Adyacentes a Campos de Hielo Sur) by the "Vidal Gormaz" along the Chilean coast between $42^{\circ} \mathrm{S}$ and $56^{\circ} \mathrm{S}$ were predominantly Chilean but with some German participation. They focused on benthic diversity and have included non-invasive underwater video since 1997 (Gorny \& Retamal in press). The major objective was to compare species composition and richness between different sub-areas and between inner parts of the fjord system and the Pacific entrances, with their relationship to fisheries in mind. Additional surveys were carried out around Easter Islands and the Juan Fernández Islands, San Felix, and San Ambrosio Island (Gorny \& Retamal 2000, 2001). Here, as with the LAMPOS cruise (see below), the major goal was to investigate the role of the islands as stepping-stones enabling species to cross the Pacific Ocean towards the South American continental shelf. The use of the same visual documentation method in Chilean waters and in Antarctica will allow a reproducible comparison of benthos diversity along the entire gradient, from temperate to very cold waters. Individual notable shallow-water activities, mainly based on scuba diving, have concentrated on anthozoans and scleractinians along the Chilean coast (Häussermann in press) and on the establishment of methods for creating inventories for shallow water benthic communities as well as the identification of the driving forces behind specific diversity patterns in the northern fjord region (Försterra in press).

The principal goal of the ongoing EASIZ program (Ecology of the Antarctic Sea Ice Zone) of SCAR (Scientific Committee on Antarctic Research) is the study of key ecological processes, especially at the organism and community level. However, the 3 international EASIZ expeditions on RV "Polarstern" (Arntz \& Gutt 1997,1999, Arntz \& Brey 2001) have also provided a wealth of taxonomic benthic data from the high Weddell Sea and the Antarctic Peninsula; only a part of this has so far been published (e.g., Gutt et al. 2000, Arntz \& Clarke 2002). A complete data set for the demersal fish fauna sampled between 1986 and 1998 is stored, together with a reference collection, at the Instituto Español de Oceanografía, Tenerife, Spain.

The EVOLANTA program (Evolution in the Antarctic), launched in 2001 by SCAR, is closely involved with the faunal and floral links, which have been maintained or newly developed since Gondwanan times, between Antarctica and the continents surrounding it. One key question is how this exchange occurred in the past, and how might it happen today -does it involve passage by the deep sea or by "island hopping"? Answers to the following questions may be helpful in solving this problem: 1) What is the relationship between gene flow in Antarctic species and circulation patterns in the atmosphere and ocean? 2) What are the effects 
of global climate change and variability on evolutionary processes? 3) Do evolutionary processes in the Antarctic, now and in the past, differ from those in other parts of the world, including the Arctic? (EVOLANTA Science and Implementation, Plan 2000).

Two recent "Polarstern" expeditions, LAMPOS (Latin American "Polarstern" Study) and ANDEEP (Antarctic Benthic Deep-Sea Biodiversity; http:// www.rrz.uni-hamburg.de/biologie/ zim/niedere2/ ANDEEP.htm), both under the EVOLANTA flag, intended to contribute to a better understanding of large scale latitudinal gradients in biodiversity patterns. LAMPOS followed the shallows and islands along the Scotia Arc, which might act as stepping-stones, whereas ANDEEP focused on the deep sea to study its role in exchange processes. The deep sea might either work as a faunal barrier or as a means for specially adapted animals to disperse in cold waters leading, for example, to polar emergence or tropical submergence. Specific objectives of ANDEEP in the Drake Passage, the northern Weddell Sea and the Scotia Sea were: 1) to survey deep-water benthos, 2) to compare, taxonomically and genetically, the Atlantic basin and the Antarctic shelf, 3) to describe habitat diversity on various scales, 4) to identify the factors shaping distribution patterns, (5) to investigate evolutionary processes, and 6) to understand exchange processes related to tectonic activities. Key issues during the LAMPOS cruise were 1) biogeographic and evolutionary links between the Antarctic and South American continents, 2) biodiversity gradients, 3) the structure of benthic and fish communities, 4) pelago-benthic coupling and (5) ecological and physiological adaptations of benthic invertebrates and fish.

Most of the programs listed above (and related activities) are linked to Antarctic research and, thus, coordinated by the Alfred Wegener Institute for Polar and Marine Research (AWI); ANDEEP was initiated by the University of Hamburg. Besides these studies in very cold regions of the world oceans, Germany has a long tradition of cooperation along the Pacific coast.

During an expedition to South Georgia by the NOAA ship "Surveyor" in 1995 contributing to the U.S. AMLR program (Antarctic Marine Living Resources), the epibenthos was intensively surveyed by underwater-video using an ROV in bays, anchorages, and fjords (Watters et al. 1995). Research activities of the 2001 PUK expedition (Interrelations between productivity and environmental conditions on the Chilean continental slope, Hebbeln et al. 2001) by the R/V "Sonne" were centered on the characteristic ecological conditions (upwelling, oxygen minimum zone, ENSO) along the Pacific coast of South America (Gallardo 1963, 1985, Arntz et al. 1991). Here the goal was to investigate to what degree gradients (e.g. in oxygen saturation, sediment properties, latitude and water depth) are reflected by benthic communities. The impact of the OMZ on macrofaunal zonation, the balance between "normal" zoobenthic fauna and sulphur bacteria, and potential ENSO impacts were the major scientific issues investigated during this cruise between Antofagasta and Chiloe, which was based on cooperation between the University of Concepción, 2 Institutes at Bremen University, and the AWI.

Research on the impacts of El Niño and La Niña also has a long-term component represented by German-Peruvian (AWI - University San Marcos, Lima) cooperation since 1981 (Arntz et al. 1985, Tarazona et al. 1996). Data on macrobenthos and environmental parameters from shallow-water fixed stations in the Bays of Ancón and Independencia $\left(12^{\circ} \mathrm{S}\right.$ and $\left.14^{\circ} \mathrm{S}\right)$ include the impact of four ENSO events, among them the two very strong ones of 1982/83 and 1997/ 98, and are the longest benthos time series available for the American Pacific coasts. Recently, this monitoring has been extended to Mejillones Bay (Antofagasta, Chile) to include a site at higher latitude.

Further German-Latin American cooperative projects, coordinated by the ZMT (Center for Tropical Marine Ecology) of Bremen University, which also cover biodiversity aspects, are located in the north of the continent (an expedition with R/V "Victor Hensen" along the Pacific coast of Costa Rica in 1993/94, Wolff \& Vargas 1994) and on the Atlantic coast: JOPS (Joint Oceanographic Projects), a multidisciplinary study off Brazil in 1994/95 with publications by various authors in Arch. Fish. Mar. Res. 47(2/3), 1999, and the ongoing MADAM project (Mangrove Dynamics and Management, see http://www.zmt.uni-bremen.de) with applied aspects concerning the use of marine resources. 


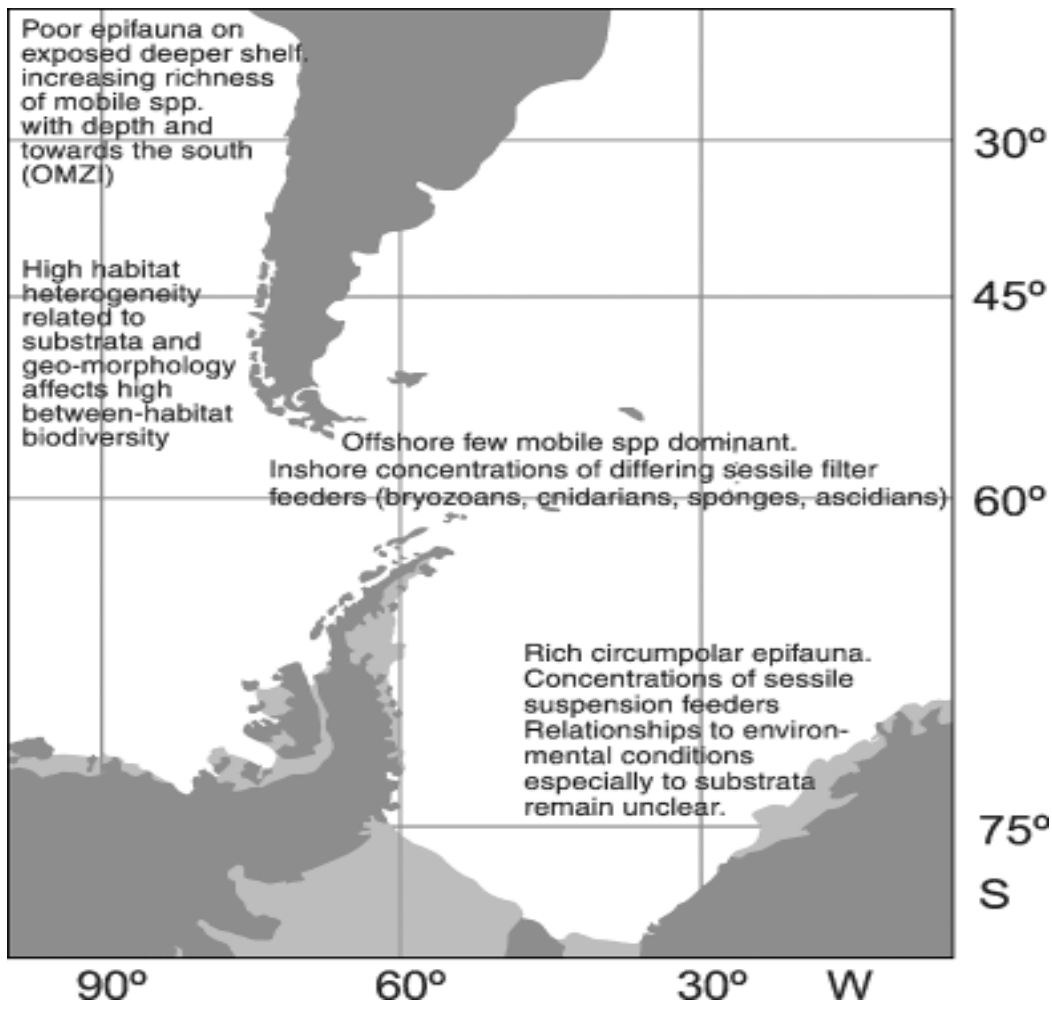

FIGURE 2. Preliminary and very brief summary of various benthos investigations related to biodiversity research (see Fig. 1).

FIGURA 2. Resumen preliminar y muy breve de las distintas investigaciones bénticas relacionadas con la investigación de la biodiversidad (ver Fig. 1).

THE KNOWN: THE DRIVING FORCES OF BIODIVERSITY ECOLOGICAL CONDITIONS VERSUS LONG-TERM DEVELOPMENT

In general, faunal surveys will show that almost each system, subsystem, or even each square meter has its own unique biological structure if a precise taxonomic level is considered. In addition, in accord with Linné "natura non facit saltus", apart from a few important exceptions, only gradients or time dependent changes in ecological phenomena are observed, rather than abrupt variations in community patterns or discrete events. These factors tend to make realistic classifications difficult. Nevertheless, wellplanned sampling strategies, advanced statistics, and the use of information in data banks can detect faunal differences if true characteristics within the eco- systems or assemblages exist. The main point in this context is the use of standard filtering techniques for reducing information for an ecosystem to manageable levels which are representative of a larger portion of the system. The first steps in this direction have already been made and these now serve as feasibility studies for recent, more advanced approaches with a more general relevance to research on evolution and ecology.

Deeper shelf areas in the Antarctic, which are exposed to the open ocean, seem to be characterized by only two or three large communities (Fig. 2). These appear to occur everywhere around the continent (for recent reviews and new original results, see Dayton 1990, Dayton et al. 1994, Faranda et al. 2000, Gutt 2000, Arntz \& Clarke 2002); certainly, 
the existence of such parallel communities in the Ross, Bellingshausen, and Weddell Seas has been confirmed (Bullivant 1967, Starmans et al. 1999). One of these is a diverse assemblage dominated by sessile suspension feeders, such as sponges, mainly colonial forms of ascidians, cnidarians, and bryozoans which seem to be more prominent in the highest latitudes (Gutt \& Starmans 1998, Gili et al. 2002, Starmans \& Gutt 2002). A similar shift to filterfeeding is observed with molluscs, among which epifaunal gastropods are more common than infaunal bivalves (Crame 1994). Various hypotheses have been developed to explain such a richness of life at depths between 100 and $800 \mathrm{~m}$ in water at $-1.5^{\circ} \mathrm{C}$, which is ice covered almost year-round. These are: 1) The low concentration of terrigenous inorganic suspended material, greater quantities of which might otherwise disturb the fragile filtering mechanisms,

2) The low abundance of true benthic predators, which elsewhere exert a higher pressure on invertebrates to use ecological niches within the sediment, 3) The coastal current that guarantees a continuous supply of fresh phytodetritus for a certain period of the year (Brandt 1995, Gili et al. 2002),

4) Habitat heterogeneity and niche fragmentation caused by epibiotic relationships (Gutt \& Schickan 1998, Arntz et al. 1994, Brandt et al. 1997),

5) The presence of a sediment with a wide range of particle sizes which allows the successful recruitment of young stages, and

6) Specific vicarious events, e.g. the "climate diversity pumps" (Clarke \& Crame 1997a), which are mainly caused by glacial advance and retreat around the continent and split formerly homogenous populations.

A benthic structure in South America that resembles this Antarctic community in some respects, though obviously not at the species level, is that on the exposed Patagonian shelf, close to its edge south of Tierra del Fuego, which is dominated by a variety of higher taxa with sessile representatives (Gutt $e t$ al. 1999).

The other large benthic community, which is found around much of Antarctica but mainly near the Antarctic Peninsula, consists of either infauna or mobile species such as crustaceans, aspidochirote sea cucumbers, ophiuroids and polychaetes (Mühlenhardt-Siegel 1988, Ramos 1999, Piepenburg et al. 2002). Weak currents and, consequently, a more vertical sedimentation of food particles are regarded as the main reason why the above mentioned deposit feeders are favored rather than the filter feeders. If this is the case, the mechanisms behind such benthic structures are similar in other areas on the Antarctic shelf and in the deeper parts of the fjords and bays in the Magellan region. There, ophiuroids, echinoids and mobile holothurians were observed to be dominant together with a low proportion of sedentary anthozoans. Abundant holes indicate the presence of an infauna, rich at least in biomass. Locally, these soft sediments were covered during the summer by a thick layer of deposited phytodetritus. For the corresponding community in the Antarctic, there are alternative explanations:

1) The growth and recruitment of many species is slow, particularly in the case of the hexactinellid sponges which contribute significantly to the rich sessile community,

2) The recolonisation of areas which were covered by grounded shelf ice during the last glaciation, has not yet been successful in regions where the epifauna are still relatively poor (Gutt 2000), and

3) "Trophic group amensalism" (Rhoads \& Young 1970, Gallardo 1987) may be an indirect effect. The rapid success of mobile deposit feeders in some areas may have impeded the settlement of sessile life forms, and creeping species avoid those areas which were first colonized by bushy and spiny sessile animals.

The demersal fish fauna show a relatively clear latitudinal gradient from the dominance of Notothenia around the Antarctic Peninsula to a population, further south, characterized by representatives from various families, Trematomus being the dominant genus. The diversity of this population increases towards the southern Weddell Sea (Hubold 1992). With the formation of the deep-sea passage between South America and Antarctica following the breakup of Gondwana (Ehrmann \& Mackensen 1992, Lawver \& Gahagan 1998), the establishment of the circumpolar current led to a significant decline in Antarctic water temperature (Crame 1992, Clarke $\&$ Crame 1992). The resulting isolation of Antarctica was probably a key event with effects on the evolution of many taxa, especially on the shelves of both continents. It could also have affected the deep-sea fauna between the continents.

The migration of taxa, especially the mobile species (e.g. notothenoid fish, isopods and amphipods) 
after the isolation of Antarctica might have been favored by the almost complete extinction of higher reptilian decapods, crustaceans in the mid Tertiary period (Klages et al. 1995, Feldmann et al. 1997). In addition, brood protection of juveniles in a marsupium as well as eurybathy (Brandt 1992, Winkler 1994, Brey et al. 1996), in the two latter systematic groups seem to have been effective as a way of a preadaptation them to short phytoplankton blooms (Arntz et al. 1997). Trophic specification using feeding strategies such as grazing on sessile suspension feeders, filter feeding, scavenging, and predation as well as the good swimming capability of some organisms may have contributed to the development of high species diversity within these groups in the Antarctic (White 1984, Coleman 1989, 1991, Klages \& Gutt 1990, De Broyer et al. 2001).

Of the various land masses that originated in Gondwana, South America has the faunal composition which is most similar to that of Antarctica. Following the Scotia Arc, South America is connected to the Falkland Islands by the shallow Burdwood Bank resulting in an overlap in species composition. Comparing faunal similarities between subantarctic regions, at least in the case of isopods, the South Shetland Islands share as many species (13) with the Magellan area as with South Georgia (Brandt 1992). From an ecological point of view, there is a similar situation in the inshore waters of South Georgia as in the Magellan region, both having a high level of dissimilarity between local assemblages of low diversity; this can be attributed to their complex coastlines. At a coarse taxonomic level, their fauna resemble that of the Antarctic continent due to the presence of a large number of species of asteroids; the locally high abundance of large glass sponges, demosponges, and alcyonarians, dense hydrozoan concentrations and the presence of animals with an epibiotic life mode such as arcturid isopods and holothurians as well as different ophiuroids, e.g. Astrotoma agassizii which is abundant in the high Antarctic (Watters et al. 1995). The LAMPOS cruise revealed that, in agreement with expectations, the northern branch of the Scotia Arc bears a great resemblance to the Magellan region, whereas the southern branch shows closer affinities to the Antarctic. However, the high variability of local sediment conditions and processes, as discussed in the "Theory of Island Biogeography” (Mac Arthur \& Wilson 1967), seems to be important. In addition, the Antarctic Convergence situated north of South Georgia is not a dis- tinct faunal boundary for the benthos, especially the deep forms; Antarctic elements occur north and Magellan elements south of the Polar Front. The South Sandwich Islands, with "inhospitable" volcanic bottoms, do not seem to have the importance as a connecting bridge that might be expected from their northsouth orientation, indicating that cross-currents must be responsible for the observed exchange.

The nature of the inshore fauna north of the Drake Passage seems to have been very much determined by recent local environmental conditions, especially where the morphology of the coastline is complex. The fjord area with slopes, depressions, and sills, the run-off from glaciers, and moraines apparently provides various microhabitats with low diversities (sensu Gray 2000) where locally only one species can be totally dominant, e.g. Munida subrugosa (Crustacea), Chaetopterus spp. (Polychaeta), brachiopods or Ophiuroglypha lymani (Ophiuroidea). If these data, which incorporate localized rich faunal communities of low abundance, were to be merged, high regional and interhabitat diversities, based on a patchwork of different assemblages, could be expected.

A first analysis of the benthos in the channel and fjord systems north of the Patagonian ice shield revealed three preliminary general results (Gorny \& Riedemann submitted): 1) As compared to the waters of the Straits of Magellan, the dominance of single species around the Taitao Peninsula is not as conspicuous as further south; 2) Within areas of low diversity, sessile filter feeders, e.g. anthozoans (Gorgonacea), followed by polychaetes (Sabellidae) and echinoids are most abundant; 3) In contrast to shallower sites, major differences between the fauna in or close to the Pacific entrances to and in the inner parts of the fjords do not exist at depths greater than about $100 \mathrm{~m}$, except in those locations situated in the vicinity of glaciers and rivers. Further information is available in Gallardo et al. (1992) and Cañete et al. (1999).

In shallow waters, sea anemones (Actiniaria), which show a significant variation in species composition between Concepción and Puerto Montt, are quite abundant and, thus, seem to be very successful in their competition for space with other taxa. Some species may even profit from human activities, such as the harvesting of other benthic organisms of economic value, which are competitors for space and food (Häussermann \& Försterra 2001). The increased density of the sea anemone populations could, though, make the resettlement of the harvested organisms more 
difficult and, thus, reduce diversity (Häussermann in press). Near vertical cliffs, dense concentrations of corals (Scleractinia) have been found in multispecies associations. These azooxanthellate corals are better known at greater depths but, in the inner fjords, populations can be found at depths as little as 10 m (Försterra \& Häussermann 2001).

The composition of the more exposed Pacific benthos further north-west seems to be shaped by major forcing factors like oxygen deficient upwelled water and the impact of ENSO. Shallow areas (100$300 \mathrm{~m}$ deep) within the OMZ were characterized by low numbers of epifaunal species with extremely poor abundances. Off Antofagasta, bacterial mats were almost the only macroscopically visible organisms, whereas holes in the sediment photographed off Concepción indicated the presence of infauna. Around Chiloé, species richness increased, the dominant groups being molluscs and decapods, crustaceans (Majidae). Greater depths (500 to 800 $\mathrm{m})$ revealed higher species numbers and abundances. Most common in all three subareas were mobile animals: molluscs, crustaceans, polychaetes, echinoderms, and fish. Among the sessile fauna, tube-building polychaetes (Onuphidae) dominated off Antofagasta whereas bryozoans and cnidarians were more frequently found off Concepción and Chiloé. Echinoids and scleractinians were very abundant at $800 \mathrm{~m}$ off Chiloé, making up almost $80 \%$ of the total haul. The epifauna between 1300 and $2000 \mathrm{~m}$ depth appeared to be less abundant but quite rich in terms of numbers of taxa, with higher diversity but smaller populations at $2000 \mathrm{~m}$. High abundances of scleractinians were observed not only at diving depths (see above) but also at $1300 \mathrm{~m}$ off Chiloé.

The benthic fauna in the OMZ off Peru is of extremely low diversity under normal and La Niña conditions, but the number of species present, as well as their abundances and biomasses, increase when El Niño events lead to flushing of the bottom water. This increase persists for several months after the end of El Niño if oxygen conditions remain favorable (Arntz et al. 1991, Tarazona et al. 1996).

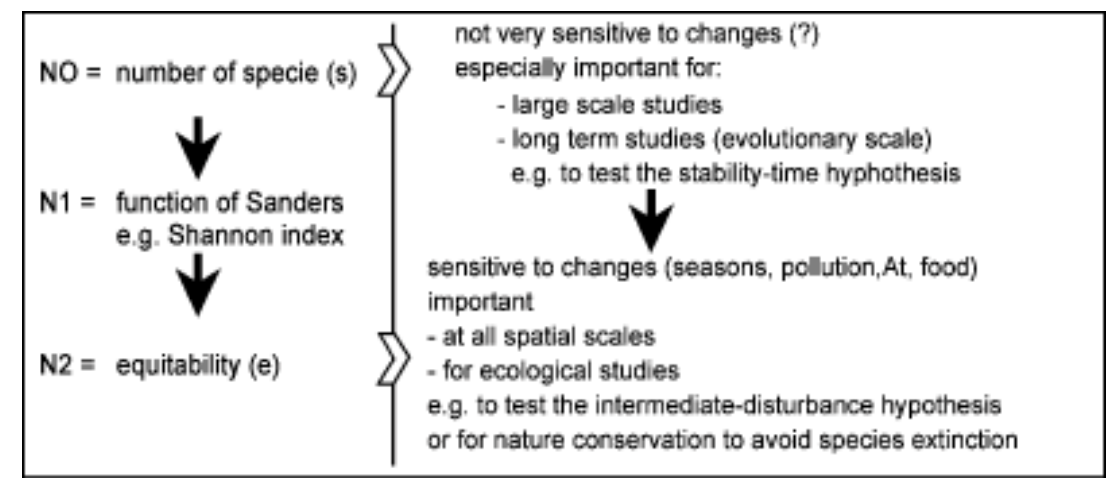

FIGURE 3. Hill's concept for classifying diversity indices according to the weighting they give to rare species; simplified after Magurran (1988) with ideas of how and when it can be applied.

Figura 3. El concepto de Hill para la clasificación de índices de diversidad según la ponderación dada a las especies raras; simplificado según Magurran (1988), con ideas de cómo y cuándo puede ser aplicado.

THE UNKNOWN: RESEARCH ON BIODIVERSITY AROUND A LARGE CONTINENT - BIG OPPORTUNITIES DEMAND BIG CONCEPTS

Research on biodiversity can hardly be defended if it is not integrated into a large-scale or even global con- text. Moreover, it is difficult to apply a concept which tries to incorporate the complexity of biodiversity (see Fig. 3 in Magurran 1988). The number of nemertines in one $\mathrm{m}^{2}$ of the coast of any place in the world is, in itself, of no great importance. On the other hand, the big questions of global diversity cannot be answered 
immediately. Therefore, it is proposed that a start be made by seeking the answers to two problems:

1. What is the large-scale species richness around South America? This has to be considered in the context of evolution related to geomorphological, glacial, and other large-scale environmental shifts. 2. How do ecological conditions influence regional diversity and can anthropogenic factors be distinguished from natural processes? Understanding how natural developments in the past affected diversity may help in forecasting the impacts of anthropogenic changes in the present and future.

Fortunately, both questions can be answered using a similar sampling strategy. For the first, it seems to be most important to sample a location in sufficient detail to be sure that the species identified represent a predetermined proportion of those expected to be present at that location (called "coverage" by Chao \& Lee 1992). All individuals sampled within a category - even if not all of the species there - have to be identified and, if necessary, newly described. The selection of specific taxa should be avoided. The value of the information obtained, even if only one assemblage is sampled, will be greatly enhanced once it is stored in a data bank and thus made available so that reliable comparisons with data sets generated by other scientists using a similar strategy can be made. Modern techniques of molecular biology provide excellent ways of complementing traditional descriptions if they allow proxies for the pace of evolution and genetic relationships to be more precisely defined. However, it is recommended that comparisons between regions or of higher taxa should be carried out within one project or in one laboratory to avoid methodological bias.

The same faunal material can also be used to answer the second question above, even if the percentage of species identified is not as high as demanded by good zoogeographical practice. Information about environmental conditions is, of course, also necessary, as only comparisons between areas with different ecological conditions will yield results which can be used for reaching conclusions in a broader context. The choice of spatial scale can significantly affect general results and conclusions (Gray 2001, Price 2002). The coverage of as broad a range of scales as possible is therefore recommended, from single point through local and regional to continental diversity, the latter being directly linked to the first question. Special attention should be paid to the definition of biodiversity. Gradients of different measures of diversity starting with just the numbers of species and then others with an increasing emphasis on equitability and a decreasing relevance of species numbers seem appropriate since they allow conclusions to be drawn about the vulnerability of an ecosystem. For the obligatory quantitative analyses, various statistical methods are available. None of these is perfect, but they provide diverse ways of error assessment and do not present significant problems against arriving at good results and realistic conclusions. The most critical point in any biodiversity program, especially if it is not supported by a single funding agency, is good coordination of the various components, i.e. sampling, species identification and enumeration, and quantitative analysis with reproducible and comparable results.

Possible comparisons that could be made are:

1) Between the exposed coastal waters over the narrow shelf off Chile and in the Antarctic;

2) Between the east and west coasts of South America, including the different ages of the two coastlines (see e.g. Gallardo \& Penchaszadeh 2001); 3) Between the fjords, straits and bays of southern South America and of the Antarctic Peninsula;

4) Between the broad Patagonian shelf and a broad shelf in the Antarctic, e.g. in the Bellingshausen Sea; 5) Between communities in warm, relatively cold, and very cold waters in the north of the continent, in upwelling areas and in the Antarctic;

6) The data from South America with those from comparable ecological situations in North America; and

7) Between the deep-sea communities in the Pacific, Atlantic, and Antarctic Oceans.

If information from truly representative communities and areas is available, the diversity patterns can be mathematically simulated. The aim of such a theoretical approach is to identify the key processes which affect the development of biodiversity, especially when this is not possible by field studies or is too expensive. In such numerical models, only one of the parameters which influence a hypothetical representative biodiversity pattern is allowed to vary at one time. The intensity of the observed changes in biodiversity provides hints on the role of this variable. This procedure can be repeated with each pa- 
rameter in turn and then with various combinations. Should such a model reach an advanced stage, forecasts for the impacts of, for instance, anthropogenically induced climate changes, mariculture, or overfishing would be possible.

\section{REFERENCES}

ArntZ, W.E., T. Brey, \& V.A. Gallardo. 1994. Antarctic zoobenthos. Oceanography and Marine Biology: an Annual Review: 32: 241-304.

ARnTZ, W. \& M. GoRnY. 1996. Cruise report of the Joint Chilean-German-Italian Magellan "Victor Hensen" Campaign in 1994. Berichte zur Polarforschung 190: 1-113.

Arntz, W. \& J. Gutt. 1997. The Expedition ANTARKTIS XIII/3 (EASIZ I) of "Polarstern" to the eastern Weddell Sea in 1996. Berichte zur Polarforschung 249: 1-148.

Arntz, W.E. \& J. Gutt. 1999. The Expedition ANTARKTIS XV/3 (EASIZ II) of RV "Polarstern" in 1998. Berichte zur Polarforschung 301: 1-229.

ARNTZ, W.E. \& C. Ríos. 1999. Magellan - Antarctic. Ecosystems that drifted apart. Scientia Marina 63 (Suplemento 1). 518 pp.

Arntz, W.E. \& T. Brey. 2001. The Expedition ANTARKTIS XVII/3 (EASIZ III) of RV "Polarstern" in 2000. Berichte zur Polarforschung 402: 1-181.

ArntZ, W.E \& A. Clarke. 2002. Ecological Studies in the Antarctic Sea Ice Zone. Springer, Berlin. 277 $\mathrm{pp}$

Arntz, W.E., A. Landa \& J. Tarazona. 1985. El Niño. $\mathrm{Su}$ impacto en la fauna marina. Boletín del Instituto del Mar del Perú - Callao (Perú). Volumen extraordinario: 1-222.

Arntz, W., W. Ernst \& I. Hempel. 1990. The Expedition ANTARKTIS VII/3 (Epos leg 3) and VII/5 of RV "Polarstern" in 1989. Berichte zur Polarforschung 68: 1-214.

Arntz, W.E., J. Gutt \& M. Klages. 1997. Antarctic marine biodiversity: an overview. In: Battaglia B.J. Valencia \& D.W.H. Walton (Eds.), Antarctic communities: 3-14. Proceedings of the 6th SCAR Biology Symposium, Venice 1994. University Press, Cambridge.

Arntz, W.E., J. Tarazona, V.A. Gallardo, L.A. Flores, \& H. SAlzwedel. 1991. Benthos communities in oxygen deficient shelf and upper slope areas of the Peruvian and Chilean Pacific coast, and changes caused by El Niño. In: Tyson R.V. \& T.H. Pearson (Eds.), Modern and ancient continental shelf anoxia: 131-154. Special Publication of the Geolocical Society of London, Volume 58.

BoschI, E.E. 2000. Species of decapod crustaceans and their distribution in the American marine zoo- geographic provinces. Revista de Investigación y Desarrollo Pesquero (Chile) 13: 7-136.

BRANDT, A. 1992. Origin of Antarctic Isopoda (Crustacea, Malacostraca). Marine Biology 113: 415-423.

Brandt, A. 1995. Peracarid fauna (Crustacea, Malacostraca) of the Northeast Water Polynya off Greenland: Documenting close benthic-pelagic coupling in the Westwind Trough. Marine Ecology Progress Series 121: 39-51.

Brandt, A., K. Linse \& U. Weber. 1997. Abundance and diversity of peracarid taxa (Crustacea, Malcostraca) along a transect through the Beagle Channel, Patagonia. Polar Biology 18: 83-90.

Brattström H. \& A. JohansSEN. 1983. Ecological and regional zoogeography of the marine benthic fauna of Chile. Sarsia 68: 289-339.

Brey, T., C. Dahm, M. Gorny, M. Klages, M. Stiller \& W.E. ARnTZ. 1996. Do Antarctic benthic invertebrates show an extended level of eurybathy. Antarctic Science 8: 3-6.

Bullivant, J.S. 1967. Ecology of the Ross Sea benthos. Bulletin of the New Zealand Department of Scientific and Industrial Research 176: 49-78.

Cañete, J.I., G.L. Leighton \& F.F. Aguilera. 1999. Polychaetes from Aysén Fjord, Chile: distribution, abundance and biogeographical comparison with the shallow soft-bottom polychaete fauna from Antarctica and the Magellan Province. In: Arntz, W.E. \& C. Ríos (Eds.), Magellan - Antarctic. Ecosystems that drifted apart: 243-252. Scientia Marine 63 (Suplemento 1).

Chao, A. \& S.-M. Lee. 1992. Estimating the number of classes via sample coverage. Journal of the American Statistical Association 87: 210-217.

Clarke, A. \& J.A. Crame. 1992. The Southern Ocean benthic fauna and climate change: a historical perspective. Philosophical Transactions of the Royal Society of London B 338: 299-309.

Clarke, A. \& J.A. Crame. 1997a. Diversity, latitude and time: Patterns in the shallow sea. In: Ormond R.F.G., J.D. Gage \& M.V. Angel (Eds.), Marine Biodiversity: Patterns and Processes: 122-147. Cambridge University Press, Cambridge.

Crame, J.A. 1992. Evolutionary history of the polar regions. Historical Biology 6: 37-60.

Crame, J.A. 1994. Evolutionary history of Antarctica. In: Hempel, G. (Ed.), Antarctic science: global concerns: 188-214. Springer, Berlin.

CRAME, J.A. 1999. An evolutionary perspective on marine faunal connections between southernmost South America and Antarctica. In: ARNTZ, W.E. \& C. Ríos (1999) Magellan - Antarctic. Ecosystems that drifted apart: 1-14. Scientia Marina 63 (Suplemento 1).

Coleman, C.O. 1989. Burrowing, grooming, and feeding behaviour of Paraceradocus, an Antarctic amphipod genus (Crustacea). Polar Biology 10: 43-48.

Coleman, C.O. 1991. Redescription of Anchiphimedia dorsalis (Crustacea, Amphipoda, Iphimediidae) from the Antarctic, and functional morphology 
of mouthparts. Zoologica Scripta 20(4): 367-374.

DAYTon, P.K. 1990. Polar benthos. In: Smith, W.O. (Ed.), Polar oceanography, Part B: Chemistry, biology, and geology: 631-685. Academic Press, San Diego.

Dayton, P.K., B.J. Mordida \& F. BACon. 1994. Polar marine communities. American Zoologist 34: 90-99.

De Broyer, C., Y. Scailteur, G. Chapelle \& M. Rauschert. 2001. Diversity and epibenthic habitats of gammaridean amphipods in the eastern Weddell Sea. Polar Biology 24: 744-753.

Ehrmann, W.U. \& A. Mackensen. 1992. Sedimentological evidence for the formation of an East Antarctic ice sheet in Eocene/Oligocene time. Palaeogeography Plaeoclimatology Palaeoecology 93: 85-112.

Fahrbach, E. \& D. Gerdes. 1997. Die Expedition ANTARKTIS XIII/4-5 des Forschungsschiffes "Polarstern" 1996. Berichte zur Polarforschung 239: 1-126.

Faranda, F.M., L. Guglielmo \& A. Ionora. 2000. Ross Sea Ecology. Springer, Berlin, 604 pp

Feldmann, R.M., M. Aguirre-Urreta, L. Chirino-Gálvez \& S. CASADío. 1997. Paleobiogeography of Cretaceous and Tertiary decapod crustaceans from southern South America: the link with Antarctica. In: RICCI, C.A. (Ed.), Antarctic region: geological evolution and processes. Proceedings of the International Symposium on Antarctic Earth Sciences, 7th, Siena, Italy, Sep. 10-15, 1995: 1007-1016. Terra Antartica Publication, Siena, Italy.

FöRSTERRA, G. IN PRESS. Reconstructing a lost world - the urgent need for practicable inventory methods. International workshop, Restoration of Benthic Invertebrate Populations in Coquimbo, November 2002.

FÖRSTERRA, G. \& V. HÄUSSERMANN. 2001. Large assemblages of azooxanthellate Scleractinia (Cnidaria: Anthozoa) in shallow waters of South Chilean fjords. Terra Nostra 01/6: 155 .

Gallardo, C.S. \& P.E. Penchaszadeh. 2001. Hatching mode and latitude in marine gastropods: revisiting Thorson's paradigm in the southern hemisphere. Marine Biology 138: 547-552.

Gallardo, V.A. 1963. Notas sobre la densidad de la fauna bentónica en el sublitoral del norte de Chile. Gayana (Zoológica) 10: 3-15.

Gallardo, V.A. 1985. Efectos del fenómeno de "El Niño" sobre el bentos sublitoral frente a Concepción, Chile. In: Arntz, W.E., A. Landa \& J. Tarazona (Eds.), El Niño. Su impacto en la fauna marina. Boletín del Instituto del Mar del Perú - Callao (Perú). Volumen extraordinario: 79-85.

GALLARDO, V.A. 1987. The sublittoral macrofaunal benthos of the Antarctic shelf. Environment International 13: 71-81.

Gallardo, V.A., O. Ferretti \& H.I. Moyano. 1992. Oceanografia in Antartide. ENEA, Progetto Antartide, Italia and Centro EULA, Universidad de Concepción, Concepción, Chile. 545 pp.

Gili, J.-M., R. Coma, C. Orejas, P.J. López-González \&
M. Zabala. 2002. Are Antarctic suspension-feeding communities different from those elsewhere in the world? In: Arntz, W.E. \& A. Clarke (Eds.), Ecological Studies in the Antarctic Sea Ice Zone: 104116. Springer, Heidelberg.

Gorny, M. \& M. Retamal. 2000. Estudio sobre la biodiversidad del Megabentos de Isla de Pascua y Salas y Gómez mediante vídeo subacuático. Libro de Resúmenes. Taller sobre los resultados del Crucero Cimar-Fiordo 5. Valparaíso, 6-7 septiembre: 119-121.

Gorny, M. \& M. Retamal. 2001. Análisis de biodiversidad del megabentos en la zona del Archipiélago de Juan Fernández y de las islas San Félix y San Ambrosio mediante un ROV. ). Libro de Resúmenes. Taller sobre los resultados del Crucero Cimar 6 Islas Oceánicas. Valparaíso, 11-12 septiembre: 123-125.

Gorny, M. \& M.A. Retamal. in press. Primeras observaciones mediante vídeo submarino y estimaciones de abundancia de crustáceos decápodos y del megabentos en la región magallánica. Ciencias Tecnología del Mar.

Gorny, M. \& A. Riedemann. SUBMtTted. Evaluación de la biodiversidad del mega - epibentos en los fiordos y canales interiores de la XI Región mediante filmaciones con un vehículo manejado a control remoto (ROV). Anales Instituto de la Patagonia, Serie Ciences Naturales.

GRAY, J.S. 2000. The measurement of marine species diversity, with an application to the benthic fauna of the Norwegian continental shelf. Journal of Experimental Marine Biology and Ecology 250: 23-249.

GraY, J.S. 2001. Marine diversity: the paradigms in patterns of species richness examined. In: Gili, J.M., J.L. Pretus \& T.T. Packard (Eds.), A Marine Science Odyssey into the 21th Century, Scientia Marina 65 (Suplemento 2): 41-56.

GuTT, J. 2000. Some "driving forces" structuring communities of the sublittoral Antarctic macrobenthos. Antarctic Science 12(3): 297-313.

GuTT, J. 2001. High latitude antarctic benthos: A "coevolution" of nature conservation and ecosystem research? Ocean and Polar Research (Korea) 23 (4): 411-417.

Gutt, J. \& A. Starmans. 1998. Structure and biodiversity of megabenthos in the Weddell and Lazarev Seas (Antarctica): ecological role of physical parameters and biological interactions. Polar Biology 20: 229-247.

GutT, J. \& T. SCHICKAN. 1998. Epibiotic relationships in the Antarctic benthos. Antarctic Science 10: 398-405.

Gutt, J., E. Helsen, W. Arntz \& A. Buschmann. 1999. Biodiversity and community structure of the megaepibenthos in the Magellan region (South America). In: Arntz, W.E. \& C. Ríos (Eds.), Magellan - Antarctic. Ecosystems that drifted apart: 155-170. Scientia Marina 63 (Suplemento 1).

GutT, J., B.I. SirenKo, W.E. ARntZ, I.S. Smirnov \& C. DE BROYER. 2000. Biodiversity of the Weddell Sea: macrozoobenthic species (demersal fish included) sampled during the expedition ANT XIII/ 
3 (EASIZ I). with RV "Polarstern" Berichte zur Polarforschung 372: 1-103.

Häussermann, V. \& G. FörsterRa. 2001. A new species of sea anemone from Chile, Anemonia alicemartinae (Cnidaria: Anthozoa). An invader or an indicator for environmental change in shallow water? Organisms Diversity \& Evolution 1(3): 211-224.

HÄUSSERMANN, V. IN PRESS. Do sea anemones inhibit resettlement of economically interesting species? International workshop, Restoration of Benthic Invertebrate Populations in Coquimbo, November 2002

HebBeln, D. \& CRUISE PARTICIPANTS. 2001. PUCK: Report and preliminary results of R/V Sonne Cruise SO 156, Valparaiso (Chile) - Talcahuano (Chile), March 29 - May 14, 2001. Berichte, Fachbereich Geowissenschaften, Universität Bremen, 182, 195 pp.

Hempel, G. 1993. Weddell Sea Ecology. Springer, Berlin. $333 \mathrm{pp}$.

HuboLd, G. 1992. Zur Ökologie der Fische im Weddellmeer. Berichte zur Polarforschung 103: 1-157.

Klages, M. \& J. Gutt. 1990. Comparative studies on the feeding behaviour of high Antarctic amphipods (Crustacea) in laboratory. Polar Biology 11: 73-79.

Klages, M., J. Gutt, A. Starmans \& T. Bruns. 1995. Stone crabs close to the Antarctic Continent: Lithodes murrayi Henderson, 1888 (Crustacea; Decapoda; Anomura) off Peter I Island (68 51'S, 9051'W). Polar Biology 15: 73-75.

Lancellotti, D.A. \& J.A. VÁsquez. 1999. Biogeographical patterns of benthic macroinvertebrates in the southeastern Pacific littoral. Journal of Biogeography 26: 1001-1006.

Lawver, L.A. \& L.M. Gahagan. 1998. Opening of Drake Passage and its impact on cenozoic ocean circulation. In: Crowley, T.J. \& K.C. Burke (Eds.), Tectonic boundary conditions for climatic reconstruction: 212-223. Oxford University Press, New York.

Mac Arthur, R.H. \& E.O. Wilson. 1967. The theory of island biogeography. Princeton University Press, Princeton, New Jersey, 203 pp.

MagurRan, A.E. 1988. Ecological diversity and its measurement. Croom Helm, London, 179 pp.

MüHLENHARDT-SIEGEL, U. 1988. Some results on quantitative investigations of macrozoobenthos in the Scotia Arc (Antarctica). Polar Biology 8: 241-248.

Piepenburg, D., J. Voss \& J. Gutt. 1997. Assemblages of sea stars (Echinodermata: Asteroidea) and brittle stars (Echinodermata: Ophiuroidea) in the Weddell Sea (Antarctica) and off Northeast Greenland (Arctic): a comparison of diversity and abundance. Polar Biology 17: 305-322.

Piepenburg, D., M.K. Schmid \& D. Gerdes. 2002. The benthos off King George Island (South Shetland Islands, Antarctica): further evidence for a lack of a latitudinal biomass cline in the Southern Ocean. Polar Biology 25: 146-158.
PricE, A.R.G. 2002. Simultaneous 'hotspots' and 'cold spots' of marine biodiversity and implications for global conservation. Marine Ecology Progress Series 241: 23-27.

Ramos, A. 1999. The megazoobenthos of the Scotia Arc islands. In: Arntz, W.E. \& C. Ríos. (Eds.) 1999. Magellan - Antarctic. Ecosystems that drifted apart: 171-182. Scientia Marina 63 (Suplemento 1).

RHoADS, D.C. \& D.K. Young. 1970. The influence of deposit-feeding organisms on sediment stability and community trophic structure. Journal of Marine Research 28: 150-178.

Starmans, A. \& J. Gutt. 2002. Mega-epibenthic diversity: a polar comparison. Marine Ecology Progress Series 225: 45-52.

Starmans, A., J. Gutt \& W.E. Arntz. 1999. Mega-epibenthic communities in Antarctic and Arctic shelf areas. Marine Biology 135: 269-280.

TARAZONA, J., W.E. ARNTZ \& E. CANAHUIRE. 1996. Impact of two "El Niño" events of different intensity on the hypoxic soft bottom macrobenthos off the central Peruvian coast. Marine Ecology 17: 425-446.

Voss, J. 1988. Zoogeographie und Gemein-schaftsanalyse des Makrobenthos des Weddellmeeres (Antarktis). Berichte zur Polarforschung 45: 1-145.

Wägele, J.-W. 1992. Benthic ecology in the Southern Ocean and the biology and evolution of Antarctic Isopoda (Crustacea: Peracarida). Verhandlungen der Deutschen Zoologischen Gesellschaft 85.2: 259-270.

Wägele, J.-W. 1994. Notes on Antarctic and South American Serolidae (Crustacea, Isopoda) with remarks on the phylogenetic biogeography and a description of new genera. Zoologisches Jahrbuch, Abteilung für Systematik 121: 3-69.

WATLING, L. \& M.H. ThURSTON. 1989. Antarctica as an evolutionary incubator: evidence from the cladistic biogeography of the amphipod family Iphimediidae. In: Crame JA (ed) Origins and evolution of the Antarctic biota: 297-313. Geological Society, special publication 47.

Watters, G., B. Bergström, J. Gutt \& J.-O. Pettersson. 1995. Preliminary report of AMLR 95 Leg II, Epifaunal surveys of bays, anchorages and fjords around South Georgia, Antarctic Journal of the US 30: $113-130$.

White, M.G. 1984. Marine benthos. In: Laws, R.M. (Ed.), Antarctic Ecology: 421-461. Vol. 2. Academic, London.

WinKLER, H. 1994. Charakterisierung der Isopodenfauna (Crustacea, Malacostraca) des Scotia-Bogens aus biogeographischer Sicht: Ein multivariater Ansatz. Berichte zur Polarforschung 139: 1-196.

WolfF, M., \& J.A. VARGAS. 1994. R.V. Victor Hensen Costa Rica Expedition 1993/1994. Cruise Report. Center for Tropical Marine Ecology (ZMT). Bremen. 109 pp. 